\title{
Effect of diurnal variation on body composition under consideration of selected chronobiological marker systems
}

\author{
Manuela Dittmar, ${ }^{1}$ Christoph Raschka, ${ }^{2}$ Horst J. Koch ${ }^{3}$ \\ ${ }^{1}$ Institute of Anthropology, Gutenberg University of Mainz, Colonel-Klein- \\ mann-Weg 2, 55099 Mainz, Germany; E-mail: dittmar@mail.uni-mainz.de \\ ${ }^{2}$ Institute of Sports Sciences, Goethe University of Frankfurt, Ginnheimer \\ Landstr. 39, 60487 Frankfurt (Main), Germany \\ ${ }^{3}$ Department of Psychiatry and Gerontopsychiatry, University Hospital of \\ Regensburg, Universitätsstr. 84, 93042 Regensburg, Germany
}

\begin{abstract}
Diurnal variation in body composition in relation to chronobiological parameters was analyzed in 27 healthy students (22-29 years) four times over one day from 5:35 to $0: 15 \mathrm{~h}$. Body composition was determined by multifrequency bioimpedance analysis at fixed frequencies $(1,5,50,100 \mathrm{kHz})$. Resistance $(\mathrm{R})$ and reactance $(\mathrm{Xc})$ were measured. Total, extra and intracellular body water (TBW, ECW, ICW), lean body mass (LBM), and fat mass (FM) were derived, and blood pressure and body temperature were measured. Friedman's ANOVA with post hoc Wilcoxon matched pairs tests revealed a diurnal variability. $\mathrm{R}$ and Xc declined in the course of the day. Weight, TBW, ECW, ICW, LBM and ECM increased, whereas height decreased. Chronobiology did not significantly influence FM. Body composition variables displayed inverse associations to $\mathrm{RR}_{\text {diastolic }}$. The diurnal decrease is probably influenced by food and fluid intake. The representative values for body composition should be the morning measures.
\end{abstract}

KEY WORDS circadian, body composition, bioimpedance, chronobiological reference values

Prz. Antropol. - Anthropol. Rev. (2002), vol. 65, pp. 17-26, Figs. 2, Tables 3. ISBN 8386969-80-6, ISSN 0033-2003

\section{Introduction}

If living matter is examined on the tissue level as a function of time under appropriate experimental conditions, nonrandom variation of the variables under study will be found. Changes associated both with nutrition and intensive training can affect the chemical composition of lean body mass [FORBES 1987]. Thus, both total body water and body hydration were higher in elite athletes than 
in non-competitive subjects [BATTISTINI et al. 1994]. Body composition is also influenced by other physiological and pharmacological variables [STEINBERG and ZASKE 1985]. Since time-dependent changes often recur in regular intervals, they represent biological rhythms. Application of specific statistical procedures allows analysis of biorhythmic function. The periods of the rhythms encountered in physical anthropology may range from seconds as in singular neurons, to about $24 \mathrm{~h}$ as in endocrinology [HAUS et al. 1989]. The name "circadian" is used rather than 24 hours to indicate the statistical nature of the special anthropologic rhythm, which may be continuously adjusted to its surroundings by external synchronizers like food intake. It became necessary for a careful exploration of body composition, which might be influenced by a variety of physiological and sociological parameters. The objectives of this study were to explore circadian changes in body composition and to analyze their relationship to chronobiological marker systems.

\section{Materials and methods}

\section{Subjects}

27 healthy volunteer ( 21 males and 6 females) sports students (mean age 24.9 yrs., range $22-29$ yrs.; mean body mass index $23.5 \mathrm{~kg} / \mathrm{m}^{2}$, range 19.0-26.9 $\mathrm{kg} / \mathrm{m}^{2}$ ) were studied at the Institute of Sports Sciences, University of Frankfurt, Germany. Each subject gave informed consent before investigation. Repeated measurements were performed four times over a period of one day from $5: 35$ to $0: 15 \mathrm{~h}$. The first measurement was performed after overnight fasting. The subjects were allowed to take small meals and drinks (up to $1500 \mathrm{~kJ}$ ) during the course of the study.

\section{Body composition}

Body composition was measured by the bioelectrical impedance technique. A tetrapolar multifrequency bioimpedance analyzer (BIA 2000-M, Data Input Company, Frankfurt, Germany), working at $800 \mu \mathrm{A}$ was used to measure at four fixed frequencies $(1,5,50$, and $100 \mathrm{kHz})$ the resistance (ohm) and reactance (ohm) of the body against an applied alternating electric current. For this, electrodes were placed on the right hand and foot of the subjects. Measurements were performed with the subjects lying in a recumbent position on a non-conductive surface, the arms and legs being abducted. Nine direct and seven estimated body composition parameters were determined; the latter were calculated by using the Nutri 4 software [Data Input 1997]: resistance ( $\mathrm{R}$, ohm), reactance (Xc, ohm), phase angle (PA, degrees), total body water (TBW, L), extra- and intracellular water (ECW, ICW, L), lean body mass (LBM, kg), extracellular mass (ECM, kg), body cell mass (BCM, $\mathrm{kg}$ ), and fat mass (FM, kg). Body composition variables were derived as follows: TBW was calculated from the resistivity index $\mathrm{Ht}^{2} / \mathrm{R}$ at $50 \mathrm{kHz}$, height, and weight using the bioimpedance equation of KUSHNER and SCHOELLER [1986], modified by the manufacturer's empirical constants. The ECW was estimated from resistance at $5 \mathrm{kHz}$, height, and weight using the equation of SEGAL et al. [1991], modified by the manufacturer's empirical constants. ICW was 
calculated as the difference between TBW and ECW. The LBM was calculated from TBW by assuming 73\% hydration of LBM as LBM = TBW/0.732. The $\mathrm{BCM}$ was calculated as $\mathrm{BCM}=$ $\mathrm{LBM} \times \ln \left(\mathrm{PA}_{50}\right) \times 0.29$, where $\mathrm{PA}$ is the phase angle measured at $50 \mathrm{kHz}$. The ECM was calculated by subtracting BCM from LBM. The FM was derived by subtracting LBM from body weight.

\section{Chronobiological marker systems}

Diastolic and systolic blood pressure, heart frequency and body temperature were also measured four times. Diastolic and systolic blood pressure and heart frequency were determined by using an automatic sphygmomanometer (Boso ${ }^{\mathrm{TM}}$, Bosch \& Son, Germany). Body temperature was measured with a Braun ThermoScan plus ear thermometer (IRT 3020, type 6012, Braun Ag, Kronberg, Germany).

\section{Statistical procedures}

Statistical analyses were performed with the Statistica release 5.0 (Tulsa, USA) and the SPSS/PC software package for MS Windows, release 8.0 (SPSS Inc., Chicago, IL). Results are given as mean values and standard deviations (SD). Variability of male and female body composition data was compared by means of coefficients of variation $(\mathrm{SD} /$ mean $\times 100)$ because they are independent of mean values. For comparison of repeated measurements, the interval data were transformed into ordinal data, because the precondition of normal distribution was not fulfilled for all variables, as shown by the Kolmogorov-Smirnov test. Therefore, comparisons of paired observations were performed by use of nonparametric Friedman's analysis of variance (ANOVA) with post hoc Wilcoxon matched pairs tests. Box plots were used for graphic representation of the results of the statistically significant Wilcoxon matched pairs tests. Relationships between variables were analyzed using Spearman correlation coefficients. Significance was set at the 0.05 level of probability (two-tailed).

\section{Results}

In order to compare variability of male and female body composition data, correlations between male and female coefficients of variation (CV) were computed (Fig. 1). The CVs correlate highly and significantly between both sexes over all body composition variables. This implies that no sex differences occur in variability. Likewise, additional $t$-tests for independent samples indicate absence of significant sex differences $(p>0.05)$. Consequently, male and female data were pooled.

Table 1 summarizes diurnal means registered for weight, height, BMI, direct and derived body composition parameters from 5:35 to $0: 15 \mathrm{~h}$. Most characters show diurnal variability. The direct body composition measures resistance, reactance, and phase angle tended to decline in the course of the day. Derived body fluid compartments (TBW, ECW and ICW) and soft tissue body composition (LBM and ECM) increased. Weight significantly increased and height decreased from morning to evening. 


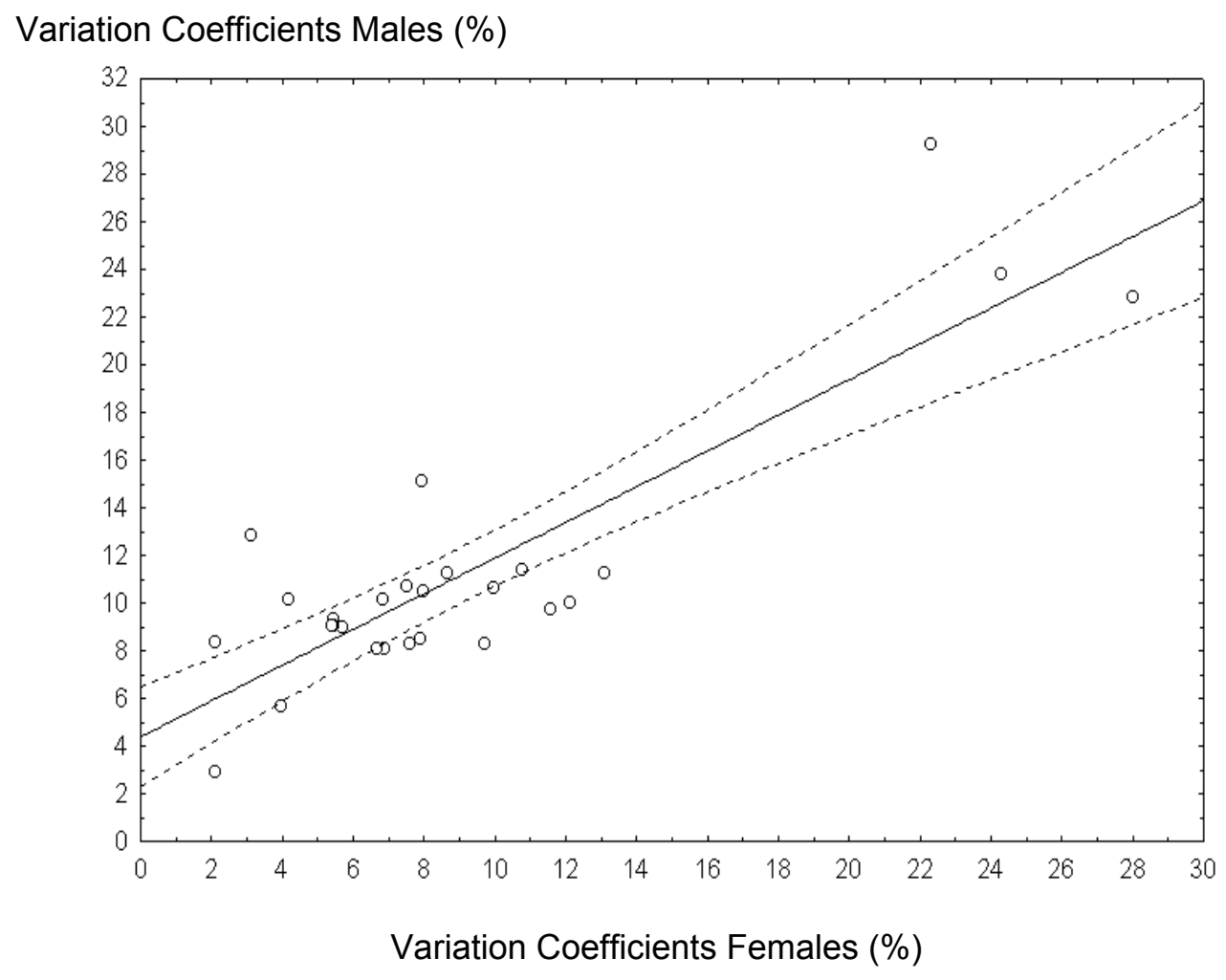

Fig. 1. Correlation (and 95\% confidence limit) between male variation coefficients $(\mathrm{VCm})$ and female variation coefficients (VCf) for body composition variables. $\mathrm{VCm}=4.39+0.75 \mathrm{VCf}(r=0.86 ; p<0.00001)$.

Table 2 gives statistical significance values for pairwise differences between consecutive measurements. Both weight and BMI show significant pairwise differences until the afternoon on the one hand and the evening measure on the other hand (Fig. 2A). Body height, however, displays its significant changes in relation to the baseline value (Fig. 2B). Significant changes in relation to the start value in the morning can also be observed for LBM, ECM, TBW, ECW and ICW (Fig. 2C, 2D).
Table 3 shows the relationships between changes in body composition and diastolic blood pressure $\left(\mathrm{RR}_{\text {diastolic }}\right)$. Body composition parameters display inverse associations to $\mathrm{RR}_{\text {diastolic, which is }}$ frequently used as a reference function for chronobiological rhythm. The observed increase in fluid compartments (TBW, ECW, and ICW) and LBM, which is dependent on water balance to a high proportion, is significantly negatively correlated to $\mathrm{RR}_{\text {diastolic }}$. $\mathrm{RR}_{\text {diastolic }}$ represents the filling condition of the vascular system. 
Table 1. Comparison of diurnal variation in body composition variables in 27 healthy volunteers

\begin{tabular}{|c|c|c|c|c|c|c|c|c|c|c|}
\hline \multirow[t]{2}{*}{ Trait } & \multicolumn{2}{|c|}{ First measure } & \multicolumn{2}{|c|}{ Second measure } & \multicolumn{2}{|c|}{ Third measure } & \multicolumn{2}{|c|}{ Fourth measure } & & \\
\hline & Mean & $\mathrm{SD}$ & Mean & $\mathrm{SD}$ & Mean & $\mathrm{SD}$ & Mean & SD & & \\
\hline $\mathrm{R}$ at $1 \mathrm{kHz}(\Omega)$ & 647.5 & 64.2 & 634.7 & 100.9 & 647.9 & 83.9 & 627.1 & 63.3 & 7.1 & 0.070 \\
\hline $\mathrm{R}$ at $5 \mathrm{kHz}(\Omega)$ & 609.5 & 66.6 & 603.5 & 63.7 & 603.9 & 67.0 & 591.9 & 64.6 & 8.3 & 0.041 \\
\hline $\mathrm{R}$ at $50 \mathrm{kHz}(\Omega)$ & 518.2 & 60.8 & 511.6 & 59.4 & 511.8 & 61.7 & 503.2 & 61.5 & 11.8 & 0.008 \\
\hline $\mathrm{Xc}$ at $5 \mathrm{kHZ}(\Omega)$ & 24.7 & 5.7 & 25.2 & 5.6 & 25.2 & 7.1 & 23.0 & 6.1 & 2.3 & 0.508 \\
\hline Xc at $50 \mathrm{kHz}(\Omega)$ & 62.3 & 8.4 & 61.8 & 7.7 & 61.4 & 7.7 & 59.6 & 6.9 & 13.0 & 0.005 \\
\hline Xc at $100 \mathrm{kHz}(\Omega)$ & 52.0 & 7.2 & 51.3 & 6.6 & 50.9 & 6.8 & 49.5 & 6.3 & 21.8 & $<0.001$ \\
\hline $\mathrm{PA}$ at $5 \mathrm{kHz}\left(^{\circ}\right)$ & 2.31 & 0.46 & 2.40 & 0.53 & 2.38 & 0.63 & 2.26 & 0.62 & 4.2 & 0.239 \\
\hline $\mathrm{PA}$ at $50 \mathrm{kHz}\left(^{\circ}\right)$ & 6.87 & 0.72 & 6.91 & 0.75 & 6.87 & 0.70 & 6.79 & 0.69 & 6.4 & 0.092 \\
\hline PA at $100 \mathrm{kHz}\left({ }^{\circ}\right)$ & 6.11 & 0.63 & 6.12 & 0.63 & 6.06 & 0.61 & 6.00 & 0.58 & 7.9 & 0.048 \\
\hline Weight (kg) & 74.5 & 9.5 & 74.4 & 9.4 & 74.5 & 9.2 & 74.9 & 9.5 & 13.1 & 0.005 \\
\hline Height (cm) & 177.9 & 8.3 & 177.2 & 8.0 & 177.4 & 8.1 & 177.2 & 7.9 & 19.6 & $<0.001$ \\
\hline BMI $\left(\mathrm{kg} / \mathrm{m}^{2}\right)$ & 23.5 & 2.0 & 23.7 & 2.0 & 23.6 & 2.0 & 23.8 & 2.0 & 23.1 & $<0.001$ \\
\hline FM (kg) & 15.4 & 4.6 & 15.2 & 4.6 & 15.2 & 4.6 & 14.9 & 4.4 & 3.7 & 0.295 \\
\hline LBM (kg) & 59.1 & 9.2 & 59.2 & 9.1 & 59.3 & 9.1 & 60.0 & 9.5 & 7.9 & 0.048 \\
\hline ECM (kg) & 26.1 & 3.9 & 26.0 & 3.6 & 26.2 & 3.7 & 26.6 & 3.8 & 12.0 & 0.008 \\
\hline BCM (kg) & 33.0 & 6.0 & 33.2 & 6.1 & 33.1 & 6.0 & 33.4 & 6.3 & 4.2 & 0.244 \\
\hline TBW (L) & 43.3 & 6.7 & 43.3 & 6.6 & 43.4 & 6.6 & 43.9 & 6.9 & 7.8 & 0.051 \\
\hline ECW (L) & 17.5 & 2.5 & 17.5 & 2.4 & 17.6 & 2.4 & 17.8 & 2.5 & 5.1 & 0.161 \\
\hline ICW (L) & 25.7 & 4.4 & 25.8 & 4.4 & 25.9 & 4.4 & 26.1 & 4.5 & 9.0 & 0.030 \\
\hline
\end{tabular}

a) Results of Friedman rank sum tests, chi-square and $p$ values, $\mathrm{df}=3$ (two-sided).

Abbreviations: BCM, body cell mass; BMI, body mass index; ECM, extracellular mass; ECW, extracellular water; FM, fat mass; ICW, intracellular water; LBM, lean body mass; PA, phase angle; R, resistance; Xc, reactance.

Significant differences are indicated in bold.

Table 2. Statistical significance of differences between pairs of consecutive measurements for the body composition variables, as assessed by Wilcoxon's matched pairs tests

\begin{tabular}{lcccccc}
\hline & \multicolumn{6}{c}{ Difference between pairs of consecutive measurements } \\
& $1-2$ & $1-3$ & $1-4$ & $2-3$ & $2-4$ & $3-4$ \\
\hline Weight $(\mathrm{kg})$ & 0.553 & 0.761 & $\mathbf{0 . 0 3 8}$ & 0.706 & $\mathbf{0 . 0 0 1}$ & $\mathbf{0 . 0 0 2}$ \\
Height $(\mathrm{cm})$ & $\mathbf{0 . 0 0 1}$ & $\mathbf{0 . 0 0 2}$ & $\mathbf{0 . 0 0 3}$ & 0.272 & 0.657 & 0.433 \\
BMI $\left(\mathrm{kg} / \mathrm{m}^{2}\right)$ & $\mathbf{0 . 0 0 6}$ & $\mathbf{0 . 0 1 2}$ & $<\mathbf{0 . 0 0 1}$ & 0.476 & 0.076 & $\mathbf{0 . 0 0 8}$ \\
FM $(\mathrm{kg})$ & 0.564 & 0.341 & 0.104 & 0.904 & 0.136 & 0.243 \\
LMB $(\mathrm{kg})$ & 0.904 & 0.534 & $\mathbf{0 . 0 1 3}$ & 0.936 & $\mathbf{0 . 0 0 7}$ & $\mathbf{0 . 0 1 6}$ \\
ECM (kg) & 0.773 & 0.524 & $\mathbf{0 . 0 1 2}$ & 0.236 & $\mathbf{0 . 0 0 1}$ & $\mathbf{0 . 0 0 4}$ \\
BCM (kg) & 0.399 & 0.346 & 0.091 & 0.558 & 0.397 & 0.247 \\
TBW (L) & 0.869 & 0.525 & $\mathbf{0 . 0 1 3}$ & 0.899 & $\mathbf{0 . 0 0 8}$ & $\mathbf{0 . 0 1 6}$ \\
ECW (L) & 0.840 & 0.808 & $\mathbf{0 . 0 2 6}$ & 0.903 & $\mathbf{0 . 0 1 2}$ & $\mathbf{0 . 0 1 5}$ \\
ICW (L) & 0.353 & 0.175 & $\mathbf{0 . 0 0 5}$ & 0.871 & $\mathbf{0 . 0 0 6}$ & $\mathbf{0 . 0 1 4}$ \\
\hline
\end{tabular}

${ }^{1} 1$ - first measurement (morning); 2 - second measurement (noon); 3 - third measurement (afternoon); 4 - fourth measurement (evening). $P$ values are shown. Significant differences are indicated in bold. 
Weight (kg)

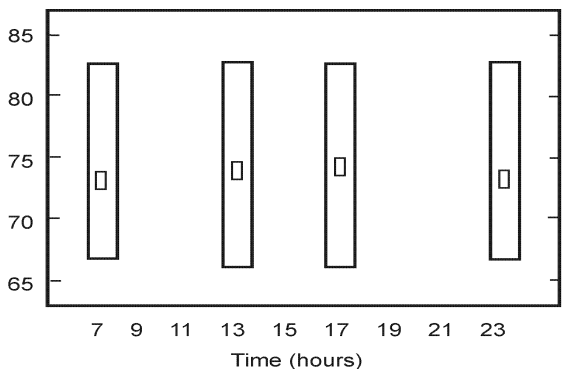

Body Mass Index $\left(\mathrm{kg} / \mathrm{m}^{2}\right)$

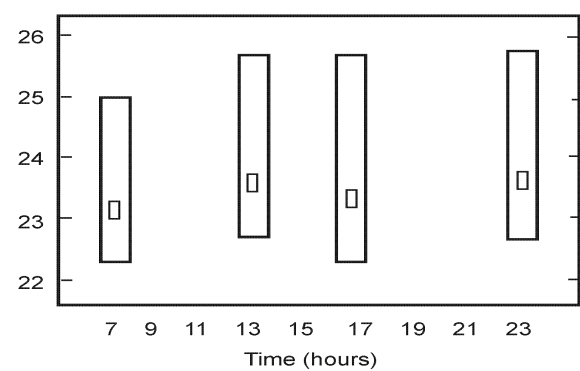

Body height $(\mathrm{m})$

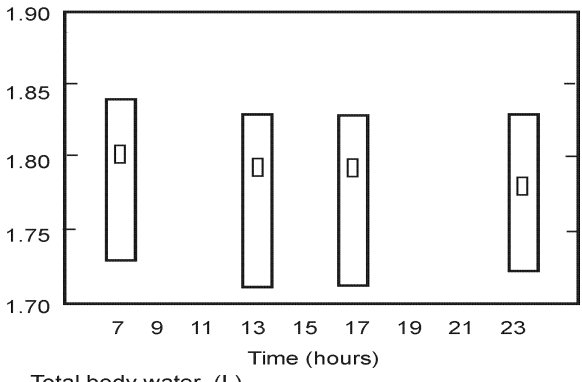

Total body water (L)

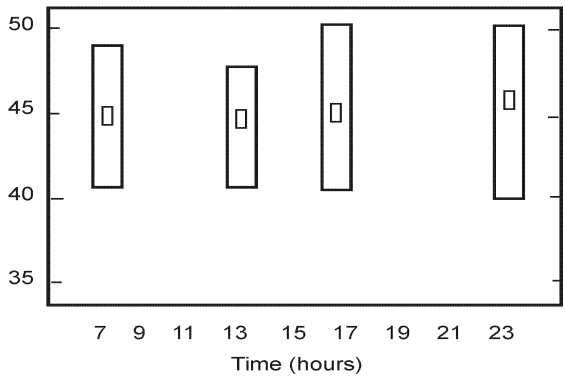

A

Extracellular water (L)

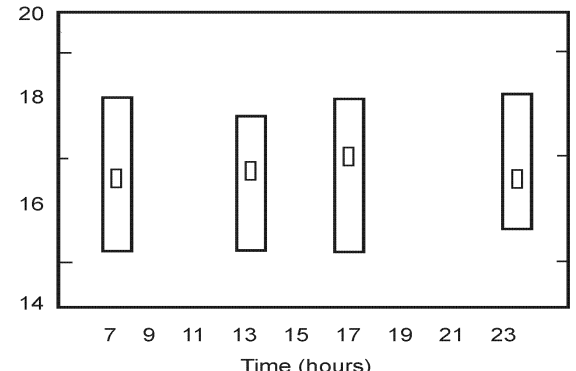

Intracellular water (L)

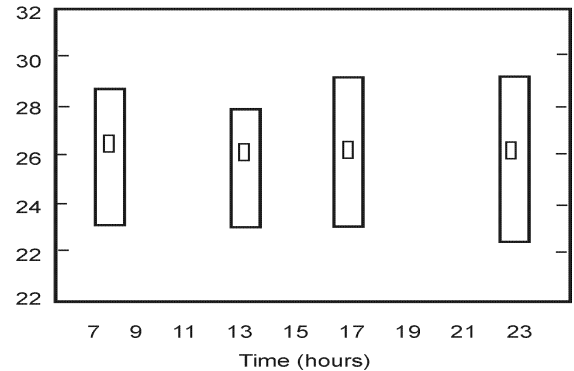

B

ean body mass $(\mathrm{kg})$

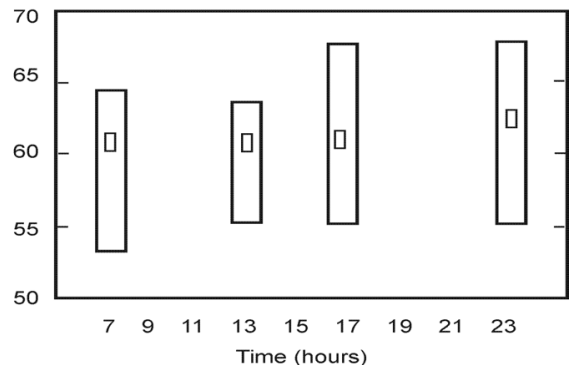

Extracellular mass $(\mathrm{kg})$

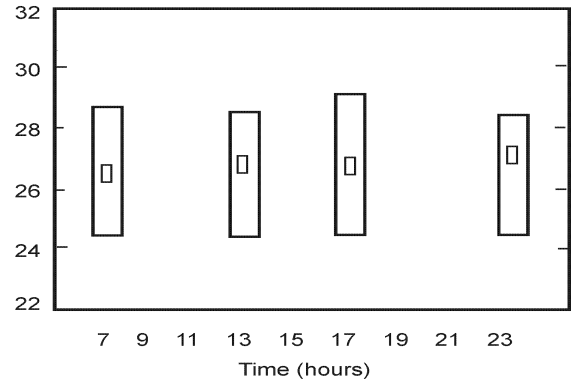

Fig. 2. Medians and $25 \%-75 \%$ intervals of observations $(N=27)$ of 4 consecutive measurements for 8 variables: A. Body weight and body mass index (BMI), B. Body height and total body water, C. Extracellular and intracellular water, and $\mathrm{D}$. Lean body mass and extracellular mass. 
Table 3. Relationships (Spearman's correlation coefficients) between changes in body composition parameters and diastolic blood pressure

\begin{tabular}{lll}
\hline Trait & \multicolumn{2}{l}{$\mathrm{RR}_{\text {diastolic }}(\mathrm{mm} \mathrm{Hg})$} \\
& $\Delta 1$ & $\Delta 2$ \\
\hline Height (cm) & $0.53^{*}$ & 0.09 \\
LBM (kg) & 0.19 & $-0.67 *$ \\
ECM (kg) & 0.05 & $-0.62 *$ \\
TBW (L) & 0.19 & $-0.67 *$ \\
ECW (L) & 0.17 & $-0.75^{* *}$ \\
ICW (L) & 0.21 & -0.55 \\
\hline
\end{tabular}

$\Delta 1$, difference between first and second measurement; $\Delta 2$, difference between second and third measurement. Significance levels: * $p<0.05, \quad * * p<0.01$

There was a significant correlation between $\Delta 2$ height and $\Delta 2$ body temperature of $r=-0.69(p<0.05)$.

\section{Discussion}

Rhythmic changes observed in anthropology may, in some instances, be a simple response to the rhythmic changes in our environment. However, some rhythms often are related to genetically fixed periodic processes. The wellknown daily decrease in body height is a function of dehydration of vertebral discs in response to the force of gravity, as was demonstrated by HILDEBRANDT [1988] and by our study (Fig. 2B). PARK [1997] describes for the diurnal variation in lumbar magnetic resonance imaging an average disc height loss of about $-10 \%$. VOSS and BAILEY [1997] found a clear decrease in stature in school children during the morning, but no further loss occurred after the subjects had been up for around six hours.

Time series data showed a significant within-day variability for weight, height, BMI, LBM, ECM, and ICW. As demonstrated by CUGINI et al. [1996], LBM and ICM showed nighttime crests. These authors hypothesized that the rest-time plays a fundamental role, via its anabolic effects, in conferring the nocturnal phase to the circadian rhythm of the human body composition. We found, additionally, a circadian increase of total body weight, which might be due to nutritional intake and fluid ingestion in the course of day. This might also be responsible for the crescent BMI. The growing LBM is based on an increase of ECM. It cannot be deduced to changes of BCM.

RODRIGUEZ et al. [2000] analyzed the influence of diurnal variation on body composition in children aged 7-15 years and found a diurnal decrease in height and an increase in BMI, LBM as has been shown in our study. RoDRIGUEZMARTINEZ et al. [1998] found an increase in both TBW and LBW for boys, aged 6-11 years, from 8:30 to 17:00 h. The same results were found in our study.

The increase in body weight is compatible with the findings of REINBERG [1992], who reported a maximum in the late afternoon. SLINDE and ROSSANDERHULTHÉN [2001] analyzed the diurnal impedance variation (measured at 50 $\mathrm{kHz}$ ) in relationship to the intake of identical meals in 18 healthy subjects during $24 \mathrm{~h}$. Bioelectrical impedance decreased after ingestion of the standard meal $(p<0.05)$. Concurrently, we found a comparable decrease for resistance at 50 $\mathrm{kHz}$. According to SLINDE and ROSSANDER-HULTHÉN [2001], the ingestion of a meal leads to a consistent decrease in impedance for $2 \mathrm{~h}$ after the first meal and for $4 \mathrm{~h}$ after the second and third meals, so that an additive effect occurred. DEURENBERG et al. [1988] reported a decrease of 13-17 $\Omega$ 2-4 $\mathrm{h}$ after intake of a liquid meal of about $2000 \mathrm{~kJ}$. 
GALLAGHER et al. [1998] observed a significant decrease in bioimpedance up to four hours after a solid meal followed by an increase up to five hours. They concluded that the decrease in bioimpedance was properly related to changes in the fluid and electrolyte distribution following absorption and digestion of food. FOGELHOLM et al. [1993] showed that resistance decreased significantly by 4-6 $\Omega 2-4 \mathrm{~h}$ after a meal with a high concentration of electrolytes, but resistance also decreased after a meal low in electrolytes. It tended to return to baseline values after $7 \mathrm{~h}$, also shown by GALLAGHER et al. [1998]. These findings confirm the changes observed in our study. RODRIGUEZ et al. [1999] described an analogous effect of impedance decrease after food intake in children and suggest that this effect may be consistent with a redistribution of extracellular fluids. SLINDE and ROSSANDER-HULTHÉN [2001] discovered increasing changes of mean ECW, calculated from multiple frequency bioimpedance measurements during $24 \mathrm{~h}$, in accordance with our results. In agreement with our findings, mean ICW also showed increasing changes during $24 \mathrm{~h}$.

In conclusion, impedance, resistance, reactance and fluid compartments decrease during the course of day. Bioimpedance values depend on concentration in body fluids. These clearly change during the day, not only with fluid and nutrient intake, but also with urination and sweating [GRIEVE and HENNEBRG 1995, 1998]. Therefore, the most representative values for body composition control should be the morning measure as is the case for weight. Circadian rhythm did not significantly influence the body fat mass. Further investigations should focus on effects of sex, ethnic affiliation, and exercise on the chronobiology of body composition. With regard to ethnic differences, JAKICIC et al. (1998) have shown that bioelectrical impedance equations underestimated LBM by $0.9 \mathrm{~kg}$ in Caucasians and overestimated it by $1.2 \mathrm{~kg}$ in African Americans.

\section{Acknowledgements}

We are indebted to the students for participation in data collection.

\section{References}

Battistini N., F. Virgili, G. Bedogni, 1994, Relative expansion of extracellular water in elite male athletes compared to recreational sportsmen, Ann. Hum. Biol., 21, 609-612

Cugini P., A. Salandri, C.M. Petrangeli, P.F. Capodaglio, C. Giovannini, 1996, Circadian rhythms in human body composition, Chronobiol. Int., 13, 359-371

Data Input, 1997, Nutri4 Handbook, Data Input Company, Frankfurt (Germany)

Deurenberg P., J. A. Weststrate, I. Paymans, K. VAN DER KOOY, 1988, Factors affecting bioelectrical impedance measurements in humans, Eur. J. Clin. Nutr., 42, 1017-22

Fogelholm M., H. SievÄNEN, K. KUKKONENHarjula, P. OJa, I. Vouri, 1993, Effects of meal and its electrolytes on bioelectrical impedance, [in:] Human body composition, K.J. Ellis and J.D. Eastman (eds.), Plenum Press, New York, 331-332

ForBES D.G., 1987, Human body composition. Growth, aging, nutrition and activity, Springer, Berlin

Gallagher M., K.Z. Walker, K. O'DeA, 1998, The influence of breakfast meal on the assessment of body composition using bioelectrical impedance, Eur. J. Clin. Nutr., 52, 94-97

Grieve C., M. HenneberG, 1995, How solid is the theoretical basis for bioelectrical impedance analysis? (letter), Am. J. Clin. Nutr., 61, 1306-1307

Grieve C., M. HenneberG, 1998, Statistical significance of body impedance measurements in estimating body composition, Homo, 49, 1-12 
Haus E., G. Nicolau, D.J. Lakatua, L. SacketTLundeEn, E. Petrescu, 1989, Circadian rhythm parameters of endocrine functions in elderly subjects during the seventh decade to the ninth decade of life, Chronobiologia, 16, 331-352

HiLDEBRANDT G., 1988, Die Bedeutung circadianer Rhythmen für die Bewegungstherapie, Z. Phys. Med. Baln. Med. Klim., 17, 126-141

JAKICIC J.M., R.R. WING, W. LANG, 1998, Bioelectrical impedance analysis to assess body composition in obese adult women: The effect of ethnicity, Int. J. Obes., 22, 243-249

Kushner R.F., D.A. Schoeller, 1986, Estimation of total body water by bioelectrical impedance analysis, Am. J. Clin. Nutr., 44, 417-424

PARK C.O., 1997, Diurnal variation in lumbar MRI. Correlation between signal intensity, disc height, and disc bulge, Yonsei Medical Journal, 38, 8-18

ReINBERG A., 1992, Les rythmes biologiques, Presses Universitaire de France, Paris, 21-23

Rodríguez G., L.A. Moreno, A. SArría, J. FletA, M. BuEno, 1999, Diurnal variation in the assessment of body composition using bioelectrical impedance in children (letter), Eur. J. Clin. Nutr., 53, 244

Rodríguez G., L.A. Moreno, A. Sarría, J. Fleta, M. Bueno, 2000, Assessment of nutritional status and body composition in children using physical anthropometry and bioelectrical impedance: Influence of diurnal variations, J. Ped. Gastroenterol. Nutr., 30, 305-309

Rodríguez-Martinez G., A. Sarria-Chueca, L. Moreno-Aznar, J. Fleta-Zaragozano, M. Bueno-SAncheZ, 1998, Diferencias entre la mañana y la tarde en la valoración nutricional del niño mediante impedancia bioeléctrica, An. Esp. Pediatr., 49, 145-150

Segal K.R., S. Burastero, A. Chun, P. CORONEL, R.N. PIERSON JR., J. WANG, 1991, Estimation of extracellular and total body water by multiple-frequency bioelectricalimpedance measurement, Am. J. Clin. Nutr., 54, 26-29

Slinde F., L. Rossander-Hulthén, 2001, Bioelectrical impedance: Effect of 3 identical meals on diurnal impedance variation and calculation of body composition, Am. J. Clin. Nutr., 74, 474-478

SteinBerg I., D.E. ZASKe, 1985, Body composition and pharmacokinetics, [in:] Body composition assessment in youth and adults, A.F. Roche (ed.), Ross Laboratories, Columbus, Ohio, 96-101

Voss L.D., B.J. BAILEY, 1997, Diurnal variation in stature: Is stretching the answer?, Arch. Dis. Child., 77, 319-322

\section{Streszczenie}

Przedmiotem badań $\mathrm{w}$ przedstawianej pracy były zmiany zachodzące w ludzkim organizmie $\mathrm{w}$ rytmie dobowym, a w szczególności dzienne zmiany składu ciała. Zmiany te badano na tle zmienności takich markerów chronobiologicznych jak ciśnienie krwi, tętno i temperatura ciała. Pomiary wykonywano czterokrotnie w ciagu dnia, od godziny 5:35 do 0:15 na grupie 27 zdrowych studentów wychowania fizycznego (26 mężczyzn i 6 kobiet) w wieku 22-29 lat (średnia wieku 24,9 lat), charakteryzujących się wskaźnikiem BMI (średnio) $23,5 \mathrm{~kg} / \mathrm{m}^{2}$. Skład ciała każdego badanego określany był czterokrotnie przy użyciu czterobiegunowego, wieloczęstotliwościowego analizatora bioimpedancji (BIA 2000-M, Data Imput Company, Frankfurt/Main), pracującego przy $800 \mu \mathrm{A}$ i dokonującego pomiaru przy czterech stałych częstotliwościach $(1,5,50,100 \mathrm{kHz})$. W trakcie pomiarów badana osoba znajdowała się w leżącej pozycji. Określano dziewięć bezpośrednich i siedem oszacowywanych parametrów składu ciała: rezystancję $(R$, mierzoną przy trzech częstotliwościach), reaktancję (Xc, przy trzech częstotliwościach), kąt fazowy (PA, przy trzech częstotliwościach), całkowitą wodę organizmu (TBW), wodę zewnątrz- i wewnątrzkomórkową (ECW i ICW), masę ciała szczupłego (LBM), masę pozakomórkową (ECM), masę komórek ciała (BCM) i masę tłuszczu (FM). 
Zmienność danych dotyczących składu ciała u mężczyzn i kobiet porównano przy użyciu współczynników wariancji (CV). Porównania powtarzanych pomiarów dokonano przy pomocy testu ANOVA Friedmana $\mathrm{z}$ testem post hoc Wilcoxona. Zależności między zmiennymi zbadano współczynnikami korelacji Spearmana. Ponieważ współczynniki zmienności badanych zmiennych u mężczyzn i kobiet były zbliżone, dane dla obu płci połączono.

Większość badanych parametrów wykazała zmienność w ciagu dnia. Wartości pomiarów bezpośrednich składu ciała (R, Xc i PA) w ciagu dnia malały, oszacowania zawartości płynów ciała (TBW, ECW i ICW) oraz tkankowych składników ciała (LBM i ECM) wzrastały. Masa ciała istotnie wzrastała w ciagu dnia a wysokość malała. Zaobserwowany wzrost zawartości płynów w poszczególnych przedziałach organizmu (TBW, ECW, ICW) oraz masy ciała szczupłego (LBM), zależnych od bilansu wodnego, był istotnie ujemnie skorelowany z rozkurczowym ciśnieniem krwi, które określa stan wypełnienia układu naczyniowego. Ponieważ wartości bioimpedancji zależą od stężenia elektrolitów w płynach ustrojowych, obserwowane wartości pomiarów zmieniają się w ciągu dnia wraz z przyjmowaniem napojów i pokarmu, jak również oddawaniem moczu i poceniem się. Za reprezentatywne dla rzeczywistego składu ciała należałoby więc uznawać pomiary dokonywane rano, podobnie jak pomiary kontrolne masy ciała. Opisane rytmy dobowe nie wpływają istotnie na masę tłuszczu w organizmie. 